\title{
Role and performance of Agri-input dealers in extension services in Coimbatore district of Tamil Nadu, India
}

\author{
S. Elakkiya* \\ Department of Agricultural Extension and Rural Sociology, Tamil Nadu Agricultural University, \\ Coimbatore - 641003 (Tamil Nadu), India \\ M. Asokhan \\ Department of Agricultural Extension and Rural Sociology, Tamil Nadu Agricultural University \\ Coimbatore - 641003 (Tamil Nadu), India \\ *Corresponding author. Email : elakkimohanur@gmail.com
}

\section{Article Info}

https://doi.org/10.31018/

jans.v13iSI.2819

Received: March 22, 2021

Revised: May 30, 2021

Accepted: June 14, 2021

\section{How to Cite}

Elakkiya, S. and Asokhan, M. (2021). Role and performance of Agri-input dealers in extension services in Coimbatore district of Tamil Nadu, India. Journal of Applied and Natural Science, 13 (SI), 156 - 161. https://doi.org/10.31018/jans.v13iSI.2819

\begin{abstract}
The present study was designed to study the role and performance of input dealers in extension services and the relationship of farmers and dealers from a farmer perspective. For this study, a survey was taken in the Coimbatore district using a purposive random sampling technique with a well-structured interview schedule. The study found that most dealers had 40-50 farmers as customer per day at peak and offseason. Regarding technical assistance given to farmers, 90.00 per cent of the farmers asked for the brand. Delivery in prime season (1.181) followed by credit period (0.633), company officials behaviour (0.600) are the primary factor in the satisfaction of dealers with the company. Regarding the level of satisfaction of the farmers, Product choice $(93.33 \%)$, Credit facility and availability of the product $(90.00 \%)$ were the primary satisfaction criteria of the farmers with input dealers. It was concluded from the study that agro chemical company have field assistant at the block and village level to assess the farmers' problem. In addition, the company having a strong research unit to develop is a need-based product for farmers. They had proper follow up activities in the farmer's field. Therefore, Agri-input dealers were the first focus of the farmers at the village level. The Agriculture department could use the Agri-input dealers to transfer technology at farmers level and its reach would be high.
\end{abstract}

Keywords: Agri-input dealers in extension, Input dealers' extension activities, Performance of dealers, Role of Agri-input dealers

\section{INTRODUCTION}

In agriculture, there are two important factors for its development i.e. Extension and Research. The development of new technologies and their associated inputs, post-harvest processing to the final marketing and prices of all the farm produce are critical in improving farm productivity. On the other side, the transfer of all such information to the farming community is an important paramount challenge for the stakeholders. The farmers are mostly unaware of the correct types and dosage required for particular agrochemicals for different crops and new technologies. Agri-input dealers playing a tremendous role in reaching the farmers by performing the dual role of providing Agri-inputs as well as technological back up to the farmers informally (Food and Agriculture Organization, 2017).
Singh (2016) stated that with new experimentations in the agro-input sector, some players have attempted to deliver total solutions to farmers, including farm and allied inputs using new distribution and marketing channels. Since 2006, the role of agro-input dealers and agro-input dealer business started receiving some attention as the likely channels for disseminating Agricultural information (International Fund For Agricultural Development, 2006).

Agri-input dealers are the chief source of farm information to the farming community with utmost credibility. Besides the supply of inputs and credit, their role in the transfer of Agricultural technology is notable and acclaimed by the farmers for their accessibility and adorability Argade et al. (2015). Despite not having formal Agricultural education, their words are very much appealing to the farmers, resulting in the development of 
strong linkage to meet their Agri-input demands.

With this background, the present study was designed to study the role and performance of Agri-input dealers in extension services. The objective was i) To study the role of Agri-input dealers in extension servicesii) To study the relationship of farmers and Agri-input dealers in farmers perspective

\section{MATERIALS AND METHODS}

Coimbatore district was purposively selected for the study. Because the vegetable production and productivity is high compare to other districts. In Coimbatore district, out of 12 blocks Thondamuthur and Madukkarai block were selected because of high vegetable production. The purposive random sampling technique was used for sampling. A sample 30 farmers and 30 Agriinput dealers were selected for the study. Ex-post facto research design was used. Regarding data collection, well- structured interview schedule was used. The role and performance of Agri-input dealers and extend of involvement of Agri-input dealers in extension activities followed Kiran et al. (2019) viz. Response priority index, percentage analysis, and mean score were used for the data analysis.

The data was collected, analyzed and are presented in the following tables. Percentage analysis, Response priority index and mean score were used to analyses the data. Role of Agri-input dealers and their performance presented in the following categories viz., Farmers as customer, Technical assistance given by dealers, Agri-input sold by dealers, pesticide recommendation to farmers, dealers and company's satisfaction level and extend of involvement of dealers in extension activities.

\section{RESULTS AND DISCUSSION}

\section{Role and performance of Agri-input dealers:}

\section{Farmers as customer per day in Agri-input shop}

From Table 1, nearly two-thirds (73.34\%) of the farmers visited the Agri-input shop at peak season, followed by 63.34 per cent of farmers visited at off-season. From the results, it is interpreted that 40-60 farmers visited the input shop during the peak and off-season. Here, peak season means the vegetable growing season.
During peak season, the farmers visited the Agri-input shop to get inputs and crop-related information. It means that at village level, farmers rectified their doubts with Agri-input dealers. In addition, the dealers had some frequent contact with farmers. This could be evidenced by the findings of Kiran et al. (2019). Kiran et al. (2019) reported that 30 to 60 farmers visiting the shop per day for more than half $(53.33 \%)$ of the Agriinput dealers, followed by 26.67 per cent of Agri-input dealers with more than 60 farmers visiting the shop per day in Telangana southern zone.

\section{Technical assistance given to farmers by the dealers}

From Table 2, the majority $(90.00 \%)$ of the farmers were asking for the brand followed by chemical $(73.33$ $\%)$ and oral expression of the problem (60.00\%). From the results, it is interpreted that, majority of the farmers well known about the brands of the product followed by chemical.

This shows the awareness and knowledge of Agri-input among the farmers. This might be due to the farmer's interest in handling the prevailing Agricultural problem more technically and further made them have more awareness and knowledge on Agri-inputs with the advice of Agri-input dealers. The above findings is in agreement with the findings of Kiran et al. (2019) who inferred that two fifth $(41.57 \%)$ of the farmers were orally expressing the problem to the Agri-input dealers followed by 34.20 per cent of the farmers directly asking for the brand.

\section{Agri-inputs sold in shop by the dealers}

Table 3, cent per cent of the farmers used pesticides in their field, followed by seeds $(80.00 \%)$ and fertilizer (56.00). one- third $(26.66 \%)$ of the farmers used other miscellaneous input in their field. The results obtained in present study were in contrast with the results of Kiran et al. 2019 who conducted study in Southern zone of Telegana state which showed two fifth $(42.12 \%)$ of pesticides were sold by the Agri-input dealers in their shops, followed by 33.95 per cent of fertilizers, 23.29 per cent of seeds and only 0.64 per cent of other miscellaneous inputs were sold in their shops.

The reason for less miscellaneous input was that the bio fertilizer and other bio inputs are slow in reaction at field level. However, the farmers need quick response

Table 1.Farmers as customer per day in Agri input shop $(n=30)$.

\begin{tabular}{llllll}
\hline & Farmers as Customer & & At peak season & \multicolumn{2}{c}{ At off season } \\
\hline S. No & Category & No. & Per cent & No. & Per cent \\
\hline 1 & 1- 20 Farmers & 0 & 0 & 11 & 36.66 \\
2 & 21- 40 Farmers & 8 & 26.66 & 19 & 63.34 \\
3 & 41- 60 Farmers & 22 & 73.34 & 0 & 0 \\
& Total & 30 & 100 & 30 & 100 \\
\hline
\end{tabular}


Table 2. Technical assistance given to farmers by the dealers $(n=30)$.

\begin{tabular}{llll}
\hline S. No & Technical assistance & No. & Per cent \\
\hline 1 & Asking for chemical & 22 & 73.33 \\
2 & Asking for brand & 27 & 90.00 \\
3 & Bringing sample for prescription & 11 & 36.67 \\
4 & Oral expression of the problem & 18 & 60.00 \\
& & & *- Multiple responses \\
\hline
\end{tabular}

Table 3. Agri-inputs sold in shop by the dealers $(n=30)$.

\begin{tabular}{lllc}
\hline S. No & Agri-inputs sold in shop & No. * & Per cent \\
\hline 1 & Fertilizer & 17 & 56.66 \\
2 & Pesticides & 30 & 100.00 \\
3 & Seeds & 24 & 80.00 \\
4 & Other miscellaneous input & 8 & 26.66 \\
& & & * Multiple responses obtained \\
\hline
\end{tabular}

Table 4. Pesticide recommendation to farmers $(n=30)$.

\begin{tabular}{llll}
\hline S. No & Pesticide recommendation to farmers & No. & Per cent \\
\hline 1 & Experiences in Input shop & 11 & 36.66 \\
2 & Companies field assistant & 17 & 56.70 \\
3 & Fellow farmer & 2 & 6.64 \\
& Total & 30 & 100 \\
\hline
\end{tabular}

Table 5. Dealers and companies satisfaction level $(n=30)$.

\begin{tabular}{llll}
\hline S. No & Parameters & RPI Score* & Rank \\
\hline 1 & Average margins (Rs.) & 0.574 & 5 \\
2 & Credit period (Days) & 0.633 & 2 \\
3 & Incentives & 0.478 & 7 \\
4 & Company officials behavior & 0.600 & 3 \\
5 & Delivery in prime season & 1.181 & 1 \\
6 & Complaint redressal & 0.552 & 6 \\
7 & Replacement of damaged product & 0.256 & 8 \\
9 & Target fixing & 0.144 & 9 \\
\hline
\end{tabular}

${ }^{*} \mathrm{RPI}$ - Response priority index

to pest and disease. This miscellaneous input was used for seed treatment purpose only.

\section{Pesticide recommendation to farmers}

Table 4 indicated that more than half the Agri-input dealers $(56.70 \%)$ were referred to companies' field assistant, followed by experience in input shop (36.66\%) and fellow farmer (6.64\%). From the results, Agri-input dealers seeking advice from the companies' field assis- tant and the experiences, which had the dealers in input shop. Each Agri-input companies had field assistant at block and village level. They used to guide Agriinput dealers. Agri-input dealers providing effective solution to farmers.

\section{Dealers and companies satisfaction level}

For this satisfaction level, response priority index analysis was used. It was constructed as a product of Pro- 
Elakkiya, S. and Asokhan, M. / J. Appl. \& Nat. Sci. 13 (SI), 156 - 161 (2021)

Table 6. Extent of Involvement of Agro-input dealers in extension activities $(n=30)$.

\begin{tabular}{|c|c|c|}
\hline S. No & Categories & Mean score \\
\hline \multicolumn{3}{|c|}{ Seed related } \\
\hline 1 & Information on seed quality & 2.26 \\
\hline 2 & Seed dressing & 1.76 \\
\hline 3 & On planting material & 2.36 \\
\hline 4 & Seed rate & 2.73 \\
\hline \multirow[t]{2}{*}{5} & Method of sowing & 2.66 \\
\hline & Total mean score & 2.36 \\
\hline \multicolumn{3}{|c|}{ Agro chemical related } \\
\hline 1 & Choice of chemicals & 2.66 \\
\hline 2 & Rate of application & 2.86 \\
\hline 3 & Side effects & 2.13 \\
\hline 4 & Methods of application & 2.40 \\
\hline \multirow[t]{2}{*}{5} & Use of bio-pesticides & 1.86 \\
\hline & Total mean score & 2.38 \\
\hline \multicolumn{3}{|c|}{ Fertilizer related } \\
\hline 1 & Choice of fertilizers & 2.63 \\
\hline 2 & Rate of application & 3.00 \\
\hline 3 & Side effects & 1.46 \\
\hline 4 & Methods of application & 2.13 \\
\hline \multirow[t]{2}{*}{5} & Use of bio-fertilizers & 1.90 \\
\hline & Total mean score & 2.22 \\
\hline \multicolumn{3}{|c|}{ Network } \\
\hline 1 & Progressive farmers & 2.16 \\
\hline 2 & Extension functionaries & 2.00 \\
\hline \multirow[t]{2}{*}{3} & Company researchers & 2.50 \\
\hline & Total mean score & 2.22 \\
\hline
\end{tabular}

portion of Responses (PR) and Priority Estimate (PE). Here, larger the Response Priority Index, the higher was the importance for that satisfaction.

From Table 5, the dealers having satisfaction with the company were delivered in prime season (1.181) followed by credit period (0.633), company officials behaviour (0.600) and accepted suggestions for product modification (0.5881). The company gave some offers to dealer viz., credit periods to pay the debt and delivery of needed products in prime season are the prime criteria in dealers and companies satisfaction level.

Extent of involvement of agro-input dealers in extension activities

From Table 6, it was revealed that Agri-input dealers are providing information on seed rate (2.73) and method of sowing (2.66) to farmers. Regarding agrochemicals, the rate of application (2.86) followed by choice of chemical (2.66) and methods of application of chemicals (2.40) was having more mean score than the overall mean score. The most predominant information is transferred to farmers by the Agri-input dealers in the area of the villages. The findings are in agreement with the findings of Argade et al. (2015). Argade et al. (2015), who studied in Maharastra state, revealed that the mean score for men agro-input dealers (2.39) was more than the women agro-input dealers (2.28). The involvement of both agro-input dealers was more in information on seed quality (3.00) and seed rate (3.00). The quality of seed and seed rate had more contribu- 
Elakkiya, S. and Asokhan, M. / J. Appl. \& Nat. Sci. 13 (SI), 156 - 161 (2021)

Table 7. Relationship of farmers and Agri input dealers in farmers perspective $(n=30)$.

\begin{tabular}{llll}
\hline S. No $\quad$ Category & No. & Per cent \\
\hline \multicolumn{1}{l}{ Adoption of chemical } & & \\
\hline 1 & Direct adoption & 14 & 46.67 \\
2 & Consultation with other farmers & 16 & 53.33 \\
\hline Level of satisfaction & Price & 6 & 20.00 \\
\hline 1 & Credit facility & 27 & 90.00 \\
2 & Brand choice & 21 & 70.00 \\
3 & Product choice & 93.33 \\
4 & Availability & 28 & 90.00 \\
5 & Quality & 27 & 73.33 \\
6 & *-Multiple responses obtained & 22 & \\
\hline
\end{tabular}

Farmers need for specific brand

\begin{tabular}{llll}
\hline 1 & Never & 4 & 13.33 \\
2 & Sometimes & 11 & 36.67 \\
3 & Always & 15 & 50.00 \\
\hline
\end{tabular}

Farmers decision during non availability of pesticide

\begin{tabular}{llll}
\hline 1 & Shift & 21 & 70.00 \\
2 & Wait & 9 & 30.00 \\
\hline \multicolumn{2}{l}{ Spraying of the pesticides by the farmers } & & 10.00 \\
\hline 1 & No fixed pattern & 3 & 33.34 \\
2 & Curative & 10 & 56.66 \\
3 & Preventive & 17 & 0 \\
\hline Safety measures while spraying pesticides & Never & & 56.66 \\
\hline 1 & Sometimes & 0 & 43.34 \\
2 & Always & 17 & 100 \\
\hline
\end{tabular}

tion towards the increasing crop productivity. This was a good sign that men and women agro-input dealers were involved more in such kind of activities.

The majority of the Agri-input dealers had a strong network with the company researchers (2.50), i.e. the agrochemical company has appointed a field assistant at block level. The assistant would assess the farmers' field about pest and diseases. This assistant and dealers would have close contact and communication

Relationship of farmers and Agri-input dealers in farmers perspective

In order to have an in-depth analysis of farmers view, this survey has taken in farmers. The data collected from the farmer about the dealers and input utilization are presented in table 7 .

Accordingly, more than half of the respondents (53.33 $\%$ ) consulted with other farmers for the adoption of chemical, followed by direct adoption (46.67\%). Regarding the level of satisfaction, the farmers, Product choice $(93.33 \%)$, Credit facility, and Availability of the product $(90.00 \%)$ were the farmers' primary satisfaction criteria with input dealers. The reason behind that is, Agri-input dealers provided with credit facility, i.e. the farmers had some credit days to repay the amount of the product purchase and Availability of product in prime season gets satisfaction to the farmers. The finding gains support from the findings of Thanganayaki \& 
Suryaprabha (2017). The study conducted in the Coimbatore district revealed that most of the respondents are satisfied that Availability of Agricultural inputs gets a high mean score of 4.13 and the price of Agricultural inputs gets a low mean score of 2.25 .

Half of the farmers were always needed for a specific brand, followed by the sometimes $(36.67 \%)$. The reason behind that, the famers had credibility in a particular product. A little less than two-thirds (70.00) of the respondents shifted their decision regarding the nonavailability of product.

Spraying pattern of pesticide, more than half $(56.66 \%)$ of the farmers were preventively applying the agro chemicals, followed by curative (33.34\%) and no fixed pattern $(10.00 \%)$. The farmers applied the chemical before the pest and disease occurrence.

More than half of the farmers $(56.66 \%)$ were following safety measures while spraying the pesticide in sometimes followed by 43.34 per cent of them were following safety measures in always. From the result, it concluded that farmers had more credibility towards Agri-input dealers. In addition, farmers consulted fellow farmers to adopt the chemicals in their field. Usually, farmers clarified their doubts with the input dealers followed by the fellow farmers. It shows the linkages of farmers and dealers at the village level.

The finding gains support from findings of Yadav and Dutta (2019), who conducted this study in Rajasthan district and reported that $78.2 \%$ of farmers were having basic knowledge of safe handling, application of pesticides and risk associated due to pesticide exposure, but they were not ready to change their attitude towards pesticide practices.

\section{Conclusion}

From the study, it could be concluded that the agrochemical company had field assistant at the block and village level to assess the farmers' problem. In addition, the company had a strong research unit to develop a need-based product for farmers in all the regional clusters of each district. Agri-input dealers and agrochemical companies had properly followed up activities in farmers' field. Dealers had a strong communication network with the company's officials. Usually, dealers asked their queries with the company officials and field staff. Therefore, the dealers' role and performance at the village level were important to farmers. Agri-input dealers were the first focus of the farmers at the village level. From the farmers' point of view, the Agricultural officers focused on progressive farmers, and their job works were mostly schemes oriented than field visits, delivery of subsidy fertilizer and chemicals at the end of the time. Therefore, the government might provide credit subsidy or scheme to Agri-input dealers. The Agriculture Department could use the Agri-input dealers to transfer technology, and its reach will be high. The Agri-input dealers needed knowledge and specific training about field level from the State Department of Agriculture, Tamil Nadu.

\section{Conflict of interest}

The authors declare that they have no conflict of interest.

\section{REFERENCES}

1. International Fund For Agricultural Development (2006). International Fund For Agricultural Development (IFAD) report Retrieved from from www.ifad.org.

2. Argade, S., A. Sarkar \& Mishra, S. (2015). Gender based involvement of agro-input dealers in extension activities in Maharashtra state, India, International Journal of Agriculture Sciences, 7(3), 470-473.

3. Singh, S. (2016). Innovative agricultural input marketing models in India: Performance and potential, Centre for Management in Agriculture, IIM, Ahmedabad.

4. Food and Agriculture Organization (2017). The future of food and agriculture - Trends and challenges. Food and Agriculture Organization (FAO) of the United Nations, Rome.

5. Thanganayaki, R. \& Suryaprabha, M. (2017). A study on buyer behaviour and satisfaction of Agricultural input products with special reference to palladam taluk. Intercontinental Journal of Marketing Research Review, 5(1),28-33

6. Kiran Kumar Reddy, U., Satya Gopal, P.V., Sailaja, V. \& Prasad, S.V. (2019). Role of Agri-Input dealers in transfer of technology. International Journal of Current Microbiology and Applied Sciences, 8(2), 2383-2388

7. Yadav, Sucheta \& Subroto Dutta (2019). A study of pesticide consumption pattern and farmer's perceptions towards pesticides: A case of Tijara Tehsil, Alwar (Rajasthan). International Journal of Current Microbiology and Applied Sciences, 8(4), 96-104. 